\title{
Relationship between arterial oxygen tension and mortality of patients in intensive care unit on mechanical ventilation support
}

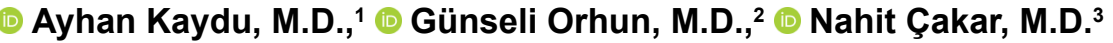

\begin{abstract}
${ }^{1}$ Department of Anesthesiology and Reanimation, Diyarbakır Selahaddin Eyyubi State Hospital, Diyarbakır-Turkey ${ }^{2}$ Department of Anesthesiology and Reanimation, İstanbul University Faculty of Medicine, İstanbul-Turkey ${ }^{3}$ Department of Anesthesiology and Reanimation, Koç University Faculty of Medicine, İstanbul-Turkey
\end{abstract}

\begin{abstract}
BACKGROUND: Although there are studies demonstrating hyperoxia may be an independent risk factor for increased mortality and morbidity, this issue remains unclear. Our research then aimed to examine the relationship between arterial oxygen tension, arterial carbon dioxide tension, and in-hospital mortality of critically ill patients in intensive care unit (ICU).

METHODS: After obtaining ethics committee approval, we analyzed a retrospective data of patients over the age of 18 who survived at least 24 hours in the ICU on mechanical ventilatory support between year 2008 and 2012 . The demographic properties, mechanical ventilation, and blood gas parameters were studied. We defined hyperoxia group as $\mathrm{PaO}_{2}$ value of $\geq 120 \mathrm{mmHg}$ and normoxemia group as $\mathrm{PaO}_{2}$ of $60-120 \mathrm{mmHg}$. Patients with $\mathrm{PaCO}_{2}$ value $<30 \mathrm{mmHg}$ were determined to have hypocapnia, those with $30-50 \mathrm{mmHg}$ normocapnia, and those with $>50 \mathrm{mmHg}$ hypercapnia.
\end{abstract}

RESULTS: Between 2008 and 2012, a total of 7689 patients were admitted to the ICU. Of 450 patients meeting the inclusion criteria of the study, 263 (58.4\%) were male and I 87 (4I.6\%) were female. Normoxia was observed in 232 (5I.5\%) patients and hyperoxia in $218(48.5 \%)$ patients. The mean $\mathrm{PaO}_{2}$ was $16.2 \mathrm{kPa}(121.50 \mathrm{mmHg})$, and $\mathrm{FiO}_{2}$ was $60 \% .254(56 \%)$ of the patients had died during the five-year period. There was no statistically significant difference in mortality between $\mathrm{PaO}_{2}$ levels and $\mathrm{PCO}_{2}$ levels $(p>0.05)$. According to the classification of $\mathrm{PaO}_{2}$ and $\mathrm{FiO}_{2}$, there was no statistically significant difference in mortality $(p>0.05)$ among patients. In addition, no statistically significant difference was found between the survival rates according to $P C O_{2}$ classification $(p=0.602, p>0.05)$.

CONCLUSION: There was no significant association between mortality and oxygen and carbon dioxide of patients in ICU on mechanical ventilatory support.

Keywords: Hyperoxia; intensive care unit; mechanical ventilation; normoxia; oxygen toxicity.

\section{INTRODUCTION}

Oxygen is one of the most frequently used therapeutic agents in the clinical settings worldwide. However, healthcare professionals, even in developed countries, have paid little attention with respect to its indications for potential use, dosage, concentrations required for administration, duration of administration, side effects, and toxicity. ${ }^{[1]}$ It was toward the end of the $19^{\text {th }}$ century that the use of oxygen became widespread in the treatment of diseases. Paul Bert and Lorrain Smith ${ }^{[2]}$ reported that oxygen at high concentrations could lead to toxicity. As shown in several animal experiments and a limited number of human studies, the administration of high doses of oxygen can cause deleterious systemic effects on other organ systems, such as the lungs, brain, and heart. ${ }^{[3-6]}$ Although there are studies which have shown that hyperoxia increased morbidity and mortality, ${ }^{[7]}$ there are also studies highlighting its benefits. ${ }^{[8-10]}$ Currently, oxygen administered to patients is

Cite this article as: Kaydu A, Orhun G, Çakar N. Relationship between arterial oxygen tension and mortality of patients in intensive care unit on mechanical ventilation support. Ulus Travma Acil Cerrahi Derg 2019;25:331-337.

Address for correspondence: Ayhan Kaydu, M.D.

Diyarbakır Selahaddin Eyyubi Devlet Hastanesi, Anesteziyoloji ve Reanimasyon Kliniği, Diyarbakır, Turkey

Tel: +90 412 - 2285430 E-mail: akaydu@hotmail.com

Ulus Travma Acil Cerrahi Derg 2019;25(4):33I-337 DOI: 10.5505/tjtes.2018.51430 Submitted: 12.10.2018 Accepted: 17.12.2018 Online: 09.07.2019

Copyright 2019 Turkish Association of Trauma and Emergency Surgery 
considered as a "drug". ${ }^{[1]}$ Despite there appear studies on the exposure time and concentration of oxygen in the body, no clear guidelines have emerged yet on this subject. ${ }^{[2,13]}$

The administration of oxygen therapy to critically ill patients is a complex process with many barriers, and it has been shown that the majority of applications have been made without sufficient evidence. ${ }^{[1-16]}$ Studying the role of oxygen toxicity in patients who are on mechanical ventilation is even more of a challenge. In a retrospective study of 50 intensive care units (ICUs), de Jonge et al. ${ }^{\left[{ }^{[7]}\right.}$ examined the relationship between mortality and arterial oxygen pressure in patients on mechanical ventilation support, and high mortality rates were observed in patients with high $\mathrm{FiO}_{2}$. They found that both low and high $\mathrm{PaO}_{2}$ increased mortality rates in the first 24 hours in ICU. ${ }^{[17]}$ In a recent similar study by Eastwood et al. ${ }^{[18]}$ hypoxia increased mortality, but no finding was reported suggesting that hyperoxia increased mortality.

The primary aim of our study was to explore the relationship between arterial oxygen tension and mortality of patients in the intensive care unit on mechanical ventilation support, high or low $\mathrm{PaO}_{2}$ in the first 24 hours being associated with mortality. Then we examine the relationship between arterial carbon dioxide tension and in-hospital mortality of patients requiring mechanical ventilation support.

\section{MATERIALS AND METHODS}

\section{Ethical Approval}

The study was granted approval by the Ethics Committee of İstanbul University Medical Faculty (Registry Url: 201 I/I790790 in accordance with the Code of Ethics of the World Medical Association-Declaration of Helsinki).

\section{Inclusion Criteria}

Our ICU is a tertiary level unit with a total of 17 beds, comprising four isolation rooms and 13 beds in the open area. The inclusion criteria were patients aged over 18 years who received mechanical ventilator support from the time of admission and had arterial blood gas analyses in the ICU. Patients with severe burns or following cardiac surgery were not included in our study. ${ }^{[17]}$ We have also excluded those with incomplete records of blood gas values, APACHE II score with diagnosis on admission, or SOFA score.

\section{Data Collection}

From the patient records, the demographic characteristics (age, gender), date of admittance to ICU, length of stay in ICU, diagnosis causing ICU admittance, comorbidities, and blood gas values (provided it was arterial blood gas) within the first 48 hours in ICU were noted on a protocol form prepared with 6-hour sections. The values were examined from the blood gas values at 6-hour intervals, including the $\mathrm{PaO}_{2}$ (arterial oxygen pressure), $\mathrm{PaCO}_{2}$ (arterial carbon diox- ide pressure), mechanical ventilation mode, PEEP (positive end-expiratory pressure), PAP (peak airway pressure), MAP (mean airway pressure), $\mathrm{FiO}_{2}$ (inspired oxygen concentration), number of sections where $\mathrm{FiO}_{2}$ decreased or increased, and the $\mathrm{PaO}_{2} / \mathrm{FiO}_{2}$ ratio.

To explore the relationship between arterial oxygen pressures and mortality, the arterial blood gas selection model described in the study by Eastwood et al. ${ }^{[18]}$ was used. Based on this model, if the $\mathrm{FiO}_{2}$ value is at least and more than 0.5 , the $\mathrm{PaO}_{2}$ value was taken as the value at the time of the highest alveolar arterial gradient (A-a), and if the $\mathrm{FiO}_{2}$ value was $<0.5$, the worst $\mathrm{PaO}_{2}$ value was taken. In case the $\mathrm{FiO}_{2}$ values taken in the first 24 hours were both less than 0.5 and at least and more than 0.5 , then the blood gas parameter was used to define as the "worst" $\mathrm{PaO}_{2}$. Following data preparation protocols, the patients were separated into two groups according to the $\mathrm{PaO}_{2}$ values. Group I was the normoxemic group with $\mathrm{PaO}_{2}$ value of $60-120 \mathrm{mmHg}$ and Group 2 was the hyperoxemic group with a $\mathrm{PaO}_{2}$ value of $\geq 120 \mathrm{mmHg}$.

Hypocapnia, normocapnia, and hypercapnia were established by taking the mean value of the $\mathrm{PCO}_{2}$ parameter throughout the follow-up period and examining these values. $\mathrm{Pa}$ tients with $\mathrm{PaCO}_{2}$ value $<30 \mathrm{mmHg}$ were determined to have hypocapnia, those with $30-50 \mathrm{mmHg}$ normocapnia, and those with $>50 \mathrm{mmHg}$ hypercapnia.

\section{Statistical Analysis}

The statistical analyses of the study findings were made by the Number Cruncher Statistical System 2007 and Power Analysis and Sample Size 2008 Statistical Software (Utah, USA) programs. Descriptive statistical methods such as the mean value, standard deviation [SD], median, and rate were used. In the comparison of quantitative data between two groups showing normal distribution of the parameters, the Student's t-test was applied, and for parameters not showing normal distribution, the Mann-Whitney U-test was employed. For comparison of qualitative data, the Continuity Correction (Yates) chi-square test and the Pearson chi-square test were used. The Kaplan-Meier analysis and the log rank test were applied to perform survival analysis. The results were evaluated with a $95 \%$ confidence interval. A value of $p<0.05$ was accepted as statistically significant.

\section{RESULTS}

450 out of 7689 patients admitted to the ICU between 2008 and 2012 who met the inclusion criteria were recruited, comprising 263 (58.4\%) males and 187 (41.6\%) females. The mean age of the patients was $59.60 \pm 16.96$ years (range: $18-93$ years).

The general characteristics of the patients according to mortality are shown in Table I. The mean age of the nonsurvivor patients was observed to be statistically significantly higher than 
Table I. General characteristics of patients according to mortality

\begin{tabular}{|c|c|c|c|}
\hline & \multicolumn{2}{|c|}{ Mortality } & \multirow[t]{2}{*}{$\mathbf{p}$} \\
\hline & Survivors $(n=195)$ & Non-survivors $(n=254)$ & \\
\hline Age (years), mean $\pm S D$ & $57.70 \pm 18.04$ & $61.05 \pm 15.99$ & ${ }^{\prime} 0.042^{*}$ \\
\hline Intensive care unit stay (days), mean \pm SD (median) & $17.31 \pm 14.6(13)$ & $13.99 \pm 15.28(9)$ & ${ }^{2} 0.001^{* *}$ \\
\hline APACHE, Mean \pm SD (median) & $18.38 \pm 6.39(18)$ & $24.61 \pm 5.99(24)$ & ${ }^{2} 0.001^{* *}$ \\
\hline Simplified Acute Physiology Score II, mean \pm SD & $39.44 \pm 13.09$ & $52.24 \pm 15.88$ & $10.001^{* *}$ \\
\hline Total mechanical ventilatory time (days), mean $\pm \mathrm{SD}$ (median) & $10.7 \pm 9.71(8)$ & $13.01 \pm 12.78(9)$ & $20.048^{*}$ \\
\hline Renal replacement therapy (days), mean $\pm S D$ (median) & $0.87 \pm 2.73(0.8)$ & $2.05 \pm 3.98(1.5)$ & ${ }^{2} 0.001^{* *}$ \\
\hline Inotrope (days), mean \pm SD (median) & $2.62 \pm 3.36(2)$ & $6.19 \pm 5.33(5)$ & ${ }^{2} 0.00 I^{* *}$ \\
\hline Male, n (\%) & III (56.9) & $15 \mid(59.4)$ & ${ }^{3} 0.590$ \\
\hline Female, n (\%) & $84(43.1)$ & $103(40.6)$ & \\
\hline
\end{tabular}

'Student t-test; ${ }^{2}$ Mann-Whitney U test; ${ }^{3}$ Pearson Ki-Kare test; ${ }^{*} \mathrm{p}<0.05 ;{ }^{* *} \mathrm{p}<0.0 \mathrm{I}$. SD: Standard deviation.

Table 2. The diagnoses of the patients on admission to ICU according to in-hospital mortality

\begin{tabular}{|c|c|c|c|c|c|}
\hline & \multicolumn{4}{|c|}{ Mortality } & \multirow[t]{3}{*}{$\mathbf{p}$} \\
\hline & \multicolumn{2}{|c|}{$\begin{array}{c}\text { Survivors } \\
(n=195)\end{array}$} & \multicolumn{2}{|c|}{$\begin{array}{c}\text { Non-survivors } \\
(n=254)\end{array}$} & \\
\hline & $\mathbf{n}$ & $\%$ & $\mathbf{n}$ & $\%$ & \\
\hline Cardiovascular & 68 & 34.9 & 87 & 34.4 & ${ }^{3} 0.915$ \\
\hline Diabetes mellitus & 38 & 19.5 & 61 & 24.0 & ${ }^{3} 0.251$ \\
\hline Hypertension & 62 & 31.8 & 87 & 34.3 & ${ }^{3} 0.584$ \\
\hline Respiratory & 30 & 15.4 & 41 & 16.2 & ${ }^{3} 0.814$ \\
\hline Renal & 21 & 10.8 & 33 & 13.0 & ${ }^{3} 0.473$ \\
\hline Gastrointestinal & 5 & 2.6 & 20 & 7.9 & ${ }^{3} 0.026^{*}$ \\
\hline Malignancy & 30 & 30 & 48 & 18.9 & ${ }^{3} 0.001^{* * 4}$ \\
\hline Hematological & 6 & 3.1 & 35 & 13.8 & ${ }^{4} 0.00 I^{* *}$ \\
\hline Neurological & 20 & 10.3 & 25 & 9.8 & ${ }^{4} I .000$ \\
\hline Other & 9 & 4.6 & 7 & 2.8 & ${ }^{4} 0.426$ \\
\hline
\end{tabular}

${ }^{3}$ Pearson Ki-Kare test; ${ }^{4}$ Yates Contiunity Correctin test; " $p<0.05$; " $p<0.01$.

ICU: Intensive care unit.

that of the survivors $(p<0.05)$. It was found that the length of stay in ICU of the survivor group was statistically significantly longer than that of the nonsurvivor group $(p<0.0 \mathrm{I})$. The total duration of mechanical ventilation, the renal replacement therapy (RRT) days, and the duration of vasopressor agent administration were also higher in the nonsurvivor group than the survivor group. The APACHE II scores and the SAPS II levels were statistically significantly higher in the nonsurvivor group than in the survivor group $(p<0.01)$.

No statistically significant relationship was found between mortality and the place from where the patient was admitted to ICU. The exitus rate was statistically significantly higher in
Table 3. The blood gas parameters of the patients according to mortality

\begin{tabular}{|c|c|c|c|}
\hline & \multicolumn{2}{|c|}{ Mortality } & \multirow[t]{3}{*}{$\mathbf{p}$} \\
\hline & $\begin{array}{l}\text { Survivors } \\
(n=195)\end{array}$ & $\begin{array}{l}\text { Non-survivors } \\
\quad(n=254)\end{array}$ & \\
\hline & Mean $\pm S D$ & Mean $\pm S D$ & \\
\hline $\mathrm{PaO}_{2}$ & $122.07 \pm 59.37$ & $115.92 \pm 46.89$ & 10.221 \\
\hline $\mathrm{FiO}_{2}$ & $0.59 \pm 0.19$ & $0.60 \pm 0.18$ & '0.74I \\
\hline $\mathrm{PaO}_{2} / \mathrm{FiO}_{2}$ & $218.82 \pm 97.81$ & $213.67 \pm 98.90$ & '0.583 \\
\hline
\end{tabular}

Table 4. The evaluation of mortality according to $\mathrm{PaO}_{2}$ classifications

\begin{tabular}{|c|c|c|c|c|c|}
\hline \multirow[t]{3}{*}{ Mortality } & \multicolumn{4}{|c|}{$\mathrm{PaO}_{2}$} & \multirow[t]{3}{*}{$\mathbf{p}$} \\
\hline & \multicolumn{2}{|c|}{$\begin{array}{c}\text { Normoxia } \\
(n=231)\end{array}$} & \multicolumn{2}{|c|}{$\begin{array}{c}\text { Hyperoxia } \\
(n=2 \mid 8)\end{array}$} & \\
\hline & $\mathbf{n}$ & $\%$ & $\mathbf{n}$ & $\%$ & \\
\hline Survivors & 102 & 44.2 & 93 & 42.7 & 0.749 \\
\hline Non-survivors & 129 & 55.8 & 125 & 57.3 & \\
\hline
\end{tabular}

Pearson chi-squared test.

the group transferred from clinics within the same hospital $(p<0.01)$, and the discharge rate was determined to be higher in the group transferred postoperatively from the operating theater $(p<0.01)$.

The diagnoses of the patients on admission to ICU according to mortality are shown in Table 2. No statistically significant difference was determined between the admission diagnoses 
Table 5. The evaluation of mortality according to $\mathrm{PaO}_{2}$ classifications

\begin{tabular}{|c|c|c|c|}
\hline & \multicolumn{2}{|c|}{$\mathrm{PaO}_{2}$} & \multirow[t]{2}{*}{$\mathbf{p}$} \\
\hline & Normoxia $(n=232)$ & Hyperoxia $(n=2 \mid 8)$ & \\
\hline Age (years) (mean $\pm S D)$ & $60.03 \pm 15.71$ & $59.14 \pm 1.26$ & $' 0.581$ \\
\hline Intensive care unit stay (days), mean \pm SD (median) & $15.65 \pm 14.36(11)$ & $15.17 \pm 15.78(10)$ & ${ }^{2} 0.189$ \\
\hline APACHE, Mean \pm SD (median) & $22.22 \pm 6.95(22)$ & $21.58 \pm 6.82(21)$ & ${ }^{2} 0.347$ \\
\hline Simplified Acute Physiology Score II, mean \pm SD & $46.54 \pm 15.48$ & $46.81 \pm 16.59$ & ${ }^{\prime} 0.857$ \\
\hline Total mechanical ventilatory time (days), mean \pm SD (median) & $|2.55 \pm| 2.7 \mid(9)$ & $11.4 \pm 10.24(8)$ & ${ }^{2} 0.371$ \\
\hline Renal replacement therapy (days), mean $\pm S D$ (median) & $1.37 \pm 3.36(0)$ & $1.7 I \pm 3.7 \mid(0)$ & ${ }^{2} 0.078$ \\
\hline Inotrope (days), mean \pm SD (median) & $4.39 \pm 4.86(3)$ & $4.89 \pm 4.94(4)$ & ${ }^{2} 0.188$ \\
\hline Male, n (\%) & $140(60.3)$ & $123(56.4)$ & ${ }^{3} 0.399$ \\
\hline Female, n (\%) & $92(39.7)$ & 95 (43.6) & \\
\hline
\end{tabular}

'Student t-test; ${ }^{2}$ Mann-Whitney $U$ test; ${ }^{3}$ Pearson Chi-squared test. SD: Standard deviation.

Table 6. The standardized mortality rate according to $\mathrm{PaO}_{2}$ and $\mathrm{FiO}_{2}$ classifications in nonsurvivor group

\begin{tabular}{lllll}
\hline Non-survivors & & \multicolumn{2}{c}{ SMR } & p \\
\cline { 3 - 4 } & & Mean & SD & \\
\hline $\mathrm{PaO}_{2}(\mathrm{mmHg})$ & $60-80$ & 0.69 & 0.16 & 0.170 \\
& $80-100$ & 0.61 & 0.18 & \\
& $100-120$ & 0.67 & 0.18 & \\
& $\geq 120$ & 0.62 & 0.20 & \\
$\mathrm{FiO}_{2}$ & $0.21-0.40$ & 0.59 & 0.19 & 0.367 \\
& $0.41-0.60$ & 0.64 & 0.19 & \\
& $0.61-0.80$ & 0.65 & 0.20 & \\
& $0.8 \mathrm{I}-1.0$ & 0.77 & 0.12 & \\
\hline
\end{tabular}

Kruskal Wallis test. SMR: Standardized mortality ratio according to SAPS II; SD: Standard deviation.

and mortality rate $(p>0.05)$ except in patients admitted for gastrointestinal, malignancy, and hematological diagnoses $(p<0.05)$.

The evaluation of the worst values and the mean values throughout the follow-up period of the blood gas parameters of the patients according to mortality is shown in Table 3. In the first 24 hours in ICU, the mean $\mathrm{PaO}_{2}$ was determined as $16.2 \mathrm{kPa}(122.44+31.8 \mathrm{mmHg})$ and mean $\mathrm{FiO}_{2}$ as $60 \%$. The $\mathrm{PaO}_{2}$ was $115.92 \pm 46 \mathrm{mmHg}$ in the nonsurvivor group and the $\mathrm{PaO}_{2}$ was $122.07 \pm 59.37 \mathrm{mmHg}$ in the survivor group. Furthermore, no significant difference was found between the two groups.

The evaluation of mortality according to $\mathrm{PaO}_{2}$ classification $(p>0.05)$ is presented in Table 4. It has been shown that there is no statistically significant difference between the survivor and nonsurvivor groups in respect of mortality.
No statistically significant difference was also seen in the length of stay in ICU, APACHE score, SAPS II, total duration of mechanical ventilation and RRT day, inotropic agent day, or gender in accordance with the $\mathrm{PaO}_{2}$ classification $(\mathrm{p}>0.05)$ (Table 5).

The survival rates of the normoxia and hyperoxia groups were evaluated using the log rank test. It can be noticed that there was no statistically significant difference between the two groups $(p=0.506, p>0.05)$ (Fig. I).

No statistically significant difference was observed between the standardized mortality rates (SMRs) according to $\mathrm{PaO}_{2}$ classification $(p>0.05)$ and $\mathrm{FiO}_{2}$ classification $(p>0.05)$ (Table 6).

Hypocapnia $\left(\mathrm{PCO}_{2}<30 \mathrm{mmHg}\right.$ ) was determined in $36(8 \%)$ patients, normocapnia ( $\left.\mathrm{PCO}_{2} 30-50 \mathrm{mmHg}\right)$ in 354 (78.7\%), and hypercapnia $\left(\mathrm{PCO}_{2}>50 \mathrm{mmHg}\right)$ in 60 (13.3\%) patients. It further revealed no statistically significant difference in mortality between patients as per the $\mathrm{PCO}_{2}$ classifications ( $p>0.05)$ (Table 7).

When the survival rates of the hypocapnia, normocapnia, and hypercapnia groups were assessed with the log rank test, they have also shown no statistically significant difference $(p=0.602, p>0.05)$ (Fig. 2).

\section{DISCUSSION}

The aim of this study was to examine the relationship between mortality and the arterial oxygen pressure and arterial carbon dioxide pressure values measured during the conducted follow-up of patients on mechanical ventilator support in ICU. From the results of this study, the following conclusions were reached:

I. No significant relationship was determined between inhospital mortality and the arterial oxygen pressure values of the first and second 24 hours. 
Table 7. Characteristics of patients according to $\mathrm{PCO}_{2}$ classifications

\begin{tabular}{|c|c|c|c|c|}
\hline & \multicolumn{3}{|c|}{$\mathrm{PCO}_{2}$} & \multirow[t]{2}{*}{$\mathbf{p}$} \\
\hline & Hypocapnia $(n=36)$ & Normocapnia $(n=354)$ & Hypercapnia $(n=60)$ & \\
\hline Age (years), mean $\pm S D$ & $63.34 \pm 12.89$ & $59.27 \pm|7.5|$ & $59.15 \pm 15.64$ & ${ }^{5} 0.330$ \\
\hline ICU stay (days), mean \pm SD (median) & $13.58 \pm \mid 1.49(10)$ & $15.32 \pm 14(11)$ & $17.1 \pm 21.63(10)$ & ${ }^{6} 0.774$ \\
\hline APACHE, mean $\pm S D$ (median) & $22.56 \pm 7.39(23)$ & $21.79 \pm 6.76(21)$ & $22.25 \pm 7.42(22)$ & ${ }^{6} 0.661$ \\
\hline SAPS II, mean \pm SD & $49.11 \pm 15.77(45.5)$ & $46.18 \pm 15.88(45)$ & $48.1 \pm 16.96(48.5)$ & ${ }^{5} 0.440$ \\
\hline Total MV Time (days), mean \pm SD (median) & $9.83 \pm 6.81(8)$ & $11.95 \pm 11.13(9)$ & $13.55 \pm 15.72(9)$ & ${ }^{6} 0.764$ \\
\hline RR (days), mean $\pm S D$ (median) & $2.58 \pm 5.39(0)$ & $1.45 \pm 3.37(0)$ & $1.4 \pm 3.03(0)$ & ${ }^{6} 0.201$ \\
\hline Inotrope (days), mean \pm SD (median) & $5.22 \pm 4.68(4)$ & $4.61 \pm 4.83(4)$ & $4.42 \pm 5.43(3)$ & ${ }^{6} 0.408$ \\
\hline Male, n (\%) & $27(75.0)$ & $203(57.3)$ & $33(55.0)$ & ${ }^{3} 0.104$ \\
\hline Female, n (\%) & $9(25.0)$ & I5I (42.7) & $27(45.0)$ & \\
\hline Survivors, n (\%) & $13(37.1)$ & I 58 (44.6) & $24(40.0)$ & ${ }^{3} 0.589$ \\
\hline Non-survivors, n (\%) & $22(62.9)$ & $196(55.4)$ & $36(60.0)$ & \\
\hline
\end{tabular}

${ }^{5}$ Oneway ANOVA test; ${ }^{6} \mathrm{Kruskal}$ Wallis test; ${ }^{3}$ Pearson Ki-Kare test.

ICU: Intensive care unit; SAPS II: Simplified Acute Physiology Score; MV:Mechanical ventilatory; RR: Renal replacement therapy; SD: Standard deviation.

2. No significant relationship was determined between inhospital mortality and the arterial carbon dioxide values.

There have been conflicting reports on the subject of the relationship between hyperoxia and mortality in studies which have examined the relationship between arterial oxygen values and mortality in patients on mechanical ventilator support. [17-20] However, our study has obtained similar results with Eastwood et al. ${ }^{[8]}$ concerning the relationship between oxygen pressure and mortality in patients on mechanical ventilator support. In their study, while there was a significant relationship between hypoxia and mortality, no relationship was established between hyperoxia and mortality. The methodology utilized by Eastwood et al. ${ }^{[18]}$ found a correlation between the $\mathrm{PaO}_{2}$ values on admittance to ICU and the peak $\mathrm{PaO}_{2}$ values in the first 24 hours. In our study, the same methodology was used in determining the worst $\mathrm{PaO}_{2}$ value in the first 24 hours. Despite similar statistical results in the two studies of mean

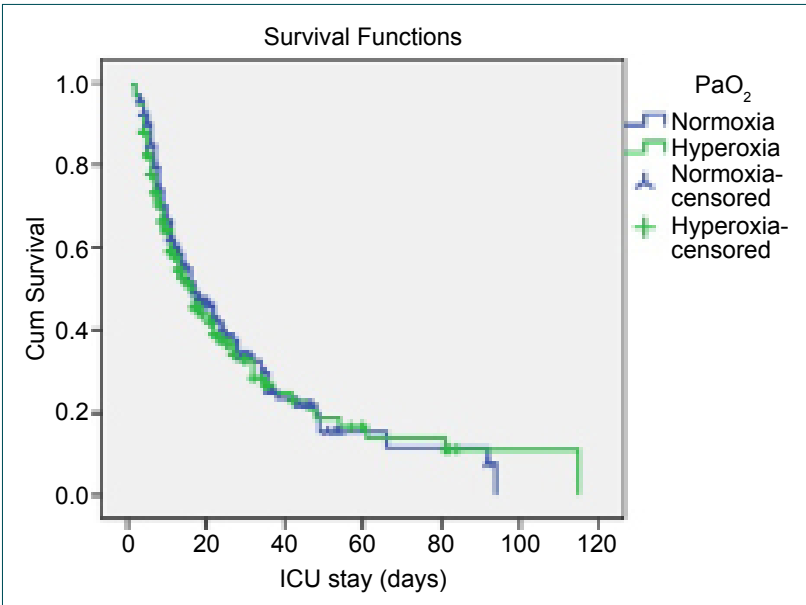

Figure 1. The survival rates of the normoxia and hyperoxia groups.
$\mathrm{PaO}_{2}$ (I5.I vs. $16.2 \mathrm{kPa}$ ) and $\mathrm{FiO}_{2}$ values (62\% vs. $60 \%$ ), a significant difference was found between the mortality values $(26 \%$ vs. $56 \%$ ). The reason for this difference could be that in the Eastwood et al. study, there were a greater number of patients being monitored in the ICU following elective surgery and the mortality of this patient group is known to be low. The SAPS II score evaluating the severity of the disease was determined to be higher (46.7 vs. 43.I) in our study compared to that of Eastwood et al. A similar study carried out by de Jonge ${ }^{[17]}$ revealed that mortality increased with high $\mathrm{FiO}_{2}$, low $\mathrm{PaO}_{2}$, and high $\mathrm{PaO}_{2}$ values in the first 24 hours in ICU. The common ground between our study and that of de Jonge et al. was the determination of high $\mathrm{FiO}_{2}\left(50.4 \%\right.$ vs. $60 \%$ ) and high $\mathrm{PaO}_{2}$ (I3.I $\mathrm{kPa}$ vs. $16.2 \mathrm{kPa}$ ) in the first 24 hours. It has been indicated that there was a significant difference in the mortality rates of patients ( $23 \%$ vs. $56 \%$ ) and there may be several reasons for this difference. The results could have been affected by the different methodologies used in determining the worst $\mathrm{PaO}_{2}$

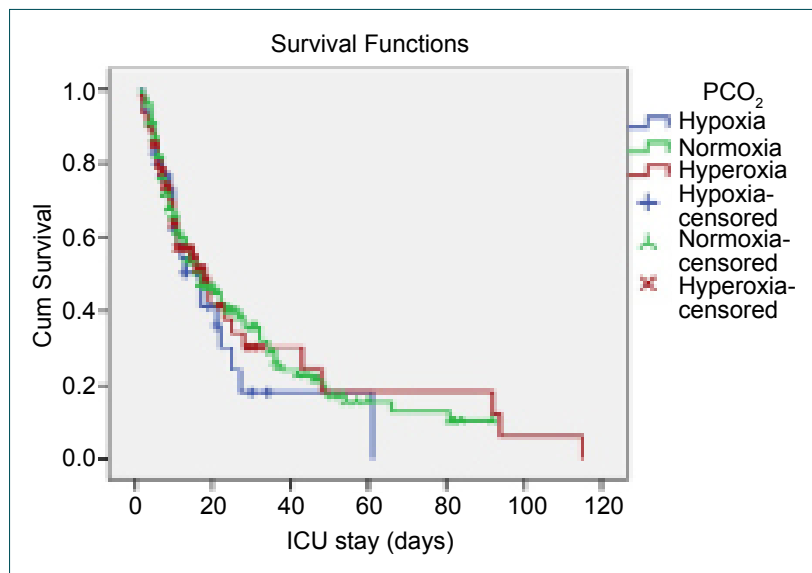

Figure 2. The survival rates of the hypocapnia, normocapnia, and hypercapnia groups. 
value in the first 24 hours (the highest alveolar arterial gradient vs. the worst $\mathrm{PaO}_{2} / \mathrm{FiO}_{2}$ ratio), differences in diagnoses on admittance, differences in ICU management, and the fact that the latter study was conducted in $\mathbf{5 0}$ different centers and there may have been differences in practices in the ICUs.

Other studies have shown that the majority of patients on mechanical ventilatory support in the ICUs are administered a large amount of oxygen and the ventilator settings are not adjusted according to hyperoxemic levels. ${ }^{[4,21]}$ In a recent prospective, randomized, controlled study of critical patient groups on mechanical ventilatory support in ICU, Suzuki et al. ${ }^{[20]}$ compared conventional and conservative oxygen treatment. They reported that restrictive oxygen therapy that aimed to keep the $\mathrm{SpO}_{2}$ value between $90 \%$ and $92 \%$ would not have any major clinical or physiological side effects. Although the mean $\mathrm{PaO}_{2}$ values of the conservative group were statistically lower than those of the conventional group $(83 \mathrm{mmHg}$ [7I-97 $\mathrm{mmHg}$ ] vs. $107 \mathrm{mmHg}$ [94-131 mmHg]), no difference was determined in terms of mortality rates. However, Girardis et al. ${ }^{[19]}$ reported lower mortality rates in the conservative group (mean $\mathrm{PaO}_{2}$ : $87 \mathrm{mmHg}$ [79-97 $\mathrm{mmHg}$ ) than the conventional group (mean $\mathrm{PaO}_{2}: 102 \mathrm{mmHg}[88-116 \mathrm{mmHg}]$ ) in a similar study. Comparing these studies with our study, the mean $\mathrm{PaO}_{2}$ values and mortality rates in our study were notably higher. This difference may be attributed to the detrimental effects of hyperoxia.

In the current study, no statistically significant relationship was determined between mortality and the hypocapnia, normocapnia, and hypercapnia groups classified according to the arterial carbon dioxide values. A recent retrospective study of a large series of patients monitored in ICU with mechanical ventilation support demonstrated that hypocapnia led to poor clinical results. ${ }^{[22,23]} \mathrm{A}$ work by Del Castillo et al. ${ }^{[24]}$ which examined the results of pediatric patients after cardiac arrest revealed that mortality has increased in hypocapnia and hypercapnia groups. In a meta-analysis of traumatic brain injury patients, Roberts et al. ${ }^{[25]}$ reported that hypocapnia and hypercapnia were reasons for poor clinical outcomes. In our study, the reasons for the different results could have been that the patients were admitted to ICU for several reasons and the study methodology was different. Hence, there is a need for further studies of larger patient groups to investigate the relationship between partial carbon dioxide values and mortality.

The most important limitation of this retrospective study was the difficulty in determining a causal relationship between oxygenation and in-hospital mortality. No clear statements have been made related to the limit values and standard categorization values, which are the most important determining factors in the relationship between arterial partial oxygen pressures and hypoxia, normoxia, and hyperoxia classifications. Hyperoxia has been described as $\mathrm{PaO}_{2}>300 \mathrm{mmHg}$ and hypoxia as $<60 \mathrm{mmHg} \mathrm{g}^{[24,26,27]}$ in some studies, but Brenner et al. ${ }^{[28]}$ defined hyperoxia as $\mathrm{PaO}_{2}>200 \mathrm{mmHg}$ and hypoxia as $<60 \mathrm{mmHg}$. de Graaff et al. ${ }^{[4]}$ and Eastwood et al. ${ }^{[18]}$ also defined hyperoxia as arterial oxygen pressure of $>16 \mathrm{kPa}$ or $120 \mathrm{mmHg}$. The international campaign for survival in sepsis and studies made on an ARDS study group recommended that in determining the clear arterial oxygen concentration values, the $\mathrm{PaO}_{2}$ value of arterial oxygen pressures in the least inspiratory oxygen fraction should be between 55 and $80 \mathrm{mmHg}$ or the arterial hemoglobin saturation should be kept between $88 \%$ and $95 \%{ }^{[29]} \mathrm{A}$ similar definition was used in the current study and the hyperoxia group was defined to have pressure $>120 \mathrm{mmHg}$. There are no standard categorizations related to oxygen values and no clear classification had affected the results of studies conducted. Our study was implemented in a single center with a limited number of patients. As previous similar studies have been made with larger patient series, it is difficult to determine the significant relationship between the two studies and to form an opinion of methods in the approach to hyperoxia in our country.

Furthermore, the total hospital stay (days) and markers of clinical conditions of the patients were not available and the reasons for ventilator adjustment were unknown. As the study was planned according to the first blood gas values only, it was not possible to come to a conclusion on how long the values remained at normoxic and hyperoxic levels and how much this affected mortality. Although no significant relationship was determined between mortality and the oxygen values of the subgroups according to the diagnoses of the patients, further studies are warranted to examine subgroups of more extensive patient series.

\section{Conclusion}

In conclusion, no significant relationship was determined between in-hospital mortality and the arterial oxygen pressure and arterial carbon dioxide pressure of patients on mechanical ventilation in ICU. In contrast to previous studies, the relationship between early hyperoxemia and mortality was unclear. As the current study was a retrospective, observational study, there is a need for further prospective, controlled research including national data collection with an organized recording system and interventional strategies to determine a causal relationship.

\section{Conflict of interest: None declared.}

\section{REFERENCES}

1. Lindahl SG. Oxygen and life on earth: an anesthesiologist's views on oxygen evolution, discovery, sensing, and utilization. Anesthesiology 2008;109:7-13. [CrossRef]

2. Hafner S, Beloncle F, Koch A, Radermacher P, Asfar P. Hyperoxia in intensive care, emergency, and peri-operative medicine: $\mathrm{Dr}$. Jekyll or Mr. Hyde? A 2015 update. Ann Intensive Care 2015;5:42. [CrossRef]

3. Sinclair SE, Altemeier WA, Matute-Bello G, Chi EY. Augmented lung injury due to interaction between hyperoxia and mechanical ventilation. Crit Care Med 2004;32:2496-501. [CrossRef]

4. de Graaff AE, Dongelmans DA, Binnekade JM, de Jonge E. Clinicians' response to hyperoxia in ventilated patients in a Dutch ICU depends on the level of FiO2. Intensive Care Med 2011;37:46-51. [CrossRef] 
5. Farquhar H, Weatherall M, Wijesinghe M, Perrin K, Ranchord A, Simmonds M, et al. Systematic review of studies of the effect of hyperoxia on coronary blood flow. Am Heart J 2009;158:371-7. [CrossRef]

6. Bhandari V, Elias JA. Cytokines in tolerance to hyperoxia-induced injury in the developing and adult lung. Free Radic Biol Med 2006;41:4-18.

7. Branson RD, Robinson BR. Oxygen: when is more the enemy of good? Intensive Care Med 2011;37:1-3. [CrossRef]

8. Balestra C, Germonpré P, Poortmans JR, Marroni A. Serum erythropoietin levels in healthy humans after a short period of normobaric and hyperbaric oxygen breathing: the "normobaric oxygen paradox".J Appl Physiol (1985) 2006;100:512-8. [CrossRef]

9. Calzia E, Asfar P, Hauser B, Matejovic M, Ballestra C, Radermacher P, et al. Hyperoxia may be beneficial. Crit Care Med 2010;38:S559-68.

10. Chura JC, Boyd A, Argenta PA. Surgical site infections and supplemental perioperative oxygen in colorectal surgery patients: a systematic review. Surg Infect (Larchmt) 2007;8:455-61. [CrossRef]

11. Bitterman H. Bench-to-bedside review: oxygen as a drug. Crit Care 2009;13:205. [CrossRef]

12. Kabon B, Kurz A. Optimal perioperative oxygen administration. Curr Opin Anaesthesiol 2006;19:11-8. [CrossRef]

13. Singer M. Give oxygen, get a blood pressure... but don't overdo it. Hosp Med 2005;66:73-5. [CrossRef]

14. Eastwood GM, Reade MC, Peck L, Jones D, Bellomo R. Intensivists' opinion and self-reported practice of oxygen therapy. Anaesth Intensive Care 2011;39:122-6. [CrossRef]

15. Eastwood GM, O'Connell B, Considine J. Oxygen delivery to patients after cardiac surgery: a medical record audit. Crit Care Resusc 2009;11:238-43.

16. O'Driscoll BR, Howard LS, Davison AG; British Thoracic Society. BTS guideline for emergency oxygen use in adult patients. Thorax 2008;63:vi1-68. [CrossRef]

17. de Jonge E, Peelen L, Keijzers PJ, Joore H, de Lange D, van der Voort $\mathrm{PH}$, et al. Association between administered oxygen, arterial partial oxygen pressure and mortality in mechanically ventilated intensive care unit patients. Crit Care 2008;12:R156. [CrossRef]

18. Eastwood G, Bellomo R, Bailey M, Taori G, Pilcher D, Young P, et al. Arterial oxygen tension and mortality in mechanically ventilated patients. Intensive Care Med 2012;38:91-8. [CrossRef]
19. Girardis M, Busani S, Damiani E, Donati A, Rinaldi L, Marudi A, et al. Effect of Conservative vs Conventional Oxygen Therapy on Mortality Among Patients in an Intensive Care Unit: The Oxygen-ICU Randomized Clinical Trial. JAMA 2016;316:1583-9. [CrossRef]

20. Suzuki S, Eastwood GM, Glassford NJ, Peck L, Young H, Garcia-Alvarez $\mathrm{M}$, et al. Conservative oxygen therapy in mechanically ventilated patients: a pilot before-and-after trial. Crit Care Med 2014;42:1414-22.

21. Rachmale S, Li G, Wilson G, Malinchoc M, Gajic O. Practice of excessive $\mathrm{F}(\mathrm{IO}(2))$ and effect on pulmonary outcomes in mechanically ventilated patients with acute lung injury. Respir Care 2012;57:1887-93.

22. Schneider AG, Eastwood GM, Bellomo R, Bailey M, Lipcsey M, Pilcher $\mathrm{D}$, et al. Arterial carbon dioxide tension and outcome in patients admitted to the intensive care unit after cardiac arrest. Resuscitation 2013;84:927-34. [CrossRef]

23. Helmerhorst HJ, Schultz MJ, van der Voort PH, de Jonge E, van Westerloo DJ. Bench-to-bedside review: the effects of hyperoxia during critical illness. Crit Care 2015;19:284. [CrossRef]

24. Del Castillo J, López-Herce J, Matamoros M, Cañadas S, Rodriguez-Calvo $\mathrm{A}$, Cechetti $\mathrm{C}$, et al. Hyperoxia, hypocapnia and hypercapnia as outcome factors after cardiac arrest in children. Resuscitation 2012;83:1456-61.

25. Roberts BW, Karagiannis P, Coletta M, Kilgannon JH, Chansky ME, Trzeciak S. Effects of PaCO2 derangements on clinical outcomes after cerebral injury: A systematic review. Resuscitation 2015;91:32-41.

26. Douzinas EE, Patsouris E, Kypriades EM, Makris DJ, Andrianakis I, Korkolopoulou P, et al. Hypoxaemic reperfusion ameliorates the histopathological changes in the pig brain after a severe global cerebral ischaemic insult. Intensive Care Med 2001;27:905-10. [CrossRef]

27. Kilgannon JH, Jones AE, Shapiro NI, Angelos MG, Milcarek B, Hunter $\mathrm{K}$, et al. Association between arterial hyperoxia following resuscitation from cardiac arrest and in-hospital mortality. JAMA 2010;303:2165-71.

28. Brenner M, Stein D, Hu P, Kufera J, Wooford M, Scalea T. Association between early hyperoxia and worse outcomes after traumatic brain injury. Arch Surg 2012;147:1042-6. [CrossRef]

29. Young P, Beasley R, Bailey M, Bellomo R, Eastwood GM, Nichol A, et al. The association between early arterial oxygenation and mortality in ventilated patients with acute ischaemic stroke. Crit Care Resusc 2012;14:14-9.

\section{DENEYSEL ÇALIŞMA - ÖZET}

\section{Yoğun bakım ünitesinde mekanik ventilatör desteği ile takip edilen hastalarda arteriyel oksijen basıncı ile mortalite arasındaki ilişki}

\section{Dr. Ayhan Kaydu, ${ }^{1}$ Dr. Günseli Orhun, ${ }^{2}$ Dr. Nahit Çakar ${ }^{3}$}

\section{'Diyarbakır Selahaddin Eyyubi Devlet Hastanesi, Anesteziyoloji ve Reanimasyon Kliniği, Diyarbakır 2'̇stanbul Üniversitesi Tıp Fakültesi, Anesteziyoloji ve Reanimasyon Anabilim Dalı, İstanbul}

${ }^{3}$ Koç Üniversitesi Tıp Fakültesi, Anesteziyoloji ve Reanimasyon Anabilim Dalı, İstanbul

AMAÇ: Hiperoksinin yoğun bakım ünitelerinde mekanik ventilasyon desteği ile takip edilen hastalarda mortalite ve morbiditeyi artıran bağımsız bir risk faktörü olduğuna dair farklı çalışmalar olmasına rağmen bu konu belirsizliğini korumaktadır.

GEREÇ VE YÖNTEM: Bu çalışma, etik komite onayı alındıktan sonra mekanik ventilatör desteği ile yoğun bakım ünitesine takip edilen 18 yaş üzerindeki 7689 hastanın ilk 24 saatteki verileri incelenerek yapılan geriye dönük, gözlemsel bir çalışmadır. Hastaların demografik özellikleri, mekanik ventilasyon ve kan gazı parametleri analiz edildi. Hiperoksemiyi $\mathrm{PaO}_{2} \geq 120 \mathrm{mmHg}$, normoksemiyi $\mathrm{PaO}_{2} 60-120 \mathrm{mmHg}$ olarak tanımlandı. PaCO değeri $<30 \mathrm{mmHg}$ olan hastalar hipokapnik, $30-50 \mathrm{mmHg}$ olanlar normokapnik, $>50 \mathrm{mmHg}$ olanlar hiperkapnik olarak tanımlandı.

BULGULAR: Hastaların yaş ortalaması $59.60 \pm 16.96$ (dağılım, I8-93) yıl idi. Ortalama $\mathrm{PaO}_{2}$ değeri $16.2 \mathrm{kPa}(\mathrm{I} 2 \mathrm{I} .50 \mathrm{mmHg})$ ve $\mathrm{FiO}_{2}$ değeri \%60 idi. İki yüz otuz iki hasta normoksi (\%5।.5) ve 218 hastada (\%48.5) hiperoksi gözlendi. Hastaların mortalite oran \%56 idi. $\mathrm{PaO}_{2}$ düzeyleri ve $\mathrm{PCO}_{2}$ düzeyleri ile mortalite arasında istatistiksel olarak anlamlı fark bulunmadı $(p>0.05)$. $\mathrm{PaO}_{2}$ ve $\mathrm{FiO}_{2}$ sınılamasına göre mortalitede istatistiksel olarak anlamlı fark yoktu ( $p>0.05)$. $\mathrm{PCO}_{2}$ sınıflamasına göre sağkalım oranları arasında istatistiksel olarak anlamlı fark bulunmadı $(p=0.602, p>0.05)$.

TARTIŞMA: Yoğun bakım ünitesindeki mekanik ventilatör desteği ile takip edilen hastalarda oksijen ve karbondioksit değerleri ile mortalite arasında anlamlı ilişki bulunmadı.

Anahtar sözcükler: Hiperoksemi; mekanik ventilasyon; normoksemi; oksijen toksisitesi; yoğun bakım ünitesi.

Ulus Travma Acil Cerrahi Derg 2019;25(4):331-337 doi: 10.5505/tjtes.20।8.5।430 